\title{
Response of root characteristics and yield in peanut under terminal drought condition
}

\author{
Junya Junjittakarn ${ }^{1}$, Teerayoot Girdthai ${ }^{2}$, Sanun Jogloy $^{1 *}$, Nimitr Vorasoot $^{1}$, and Aran Patanothai $^{1}$
}

\begin{abstract}
Drought at pod filling reduces growth, yield, and seed quality of peanut (Arachis hypogaea L.) Great root system can reduce yield loss under water stress. There is a lack of information on root traits for peanut genotypes and the relationship between rooting traits and peanut yield under terminal drought. The pot experiments were conducted at Khon Kaen University, Thailand, in 2004-2005 and 2005-2006. A randomized complete block design was used with two factorials set-up with four replicates. Factor A consisted of two water regimes (field capacity and 1/3 available water at $80 \mathrm{~d}$ after planting to harvest), and factor B comprised of 11 peanut genotypes. Data were recorded for root traits (root dry weight, root length, root surface, root diameter, and root volume), and peanut yield (pod dry weight, biomass, and harvest index) were measured at final harvest. Terminal drought significantly decrease root characteristics $\left(0.83-1.03 \mathrm{~g} \mathrm{plant}^{-1}\right.$ of root dry weight) and peanut yield (7.98-8.89 $\mathrm{g} \mathrm{plant}^{-1}$ of pod dry weight). Yield responses to terminal drought were not correlated with root traits except root length and root volume $\left(\mathrm{r}=0.71^{* *}\right.$ and $0.83^{* *}$, respectively). Some genotype, root traits seem to be correlated with peanut yield under terminal drought. 'KK60-3' showed high root traits, maintained pod dry weight under terminal drought, whereas Tifton 8 maintained biomass production. ICGV98348 had high root traits, maintained pod dry weight and harvest index under drought conditions. The results suggested that peanut contained high root characters which maintained yield under terminal drought.
\end{abstract}

Key words: Arachis hypogaea, drought tolerance, groundnut, harvest index, pod yield, root traits.

\section{INTRODUCTION}

Peanut (Arachis hypogaea L.) is produced in rain-fed areas where there is a high variation of rainfall and poor rain distribution (Nageswara Rao et al., 1989). Low and unpredictable rainfall causes severe reduction in yield, low seed quality and aflatoxin contamination of peanut (Holbrook and Stalker, 2003). Yield losses are dependent largely on drought duration and crop growth stages (Wright and Nageswara Rao, 1994). Terminal drought stress is typical of end season where the crop grows and matures on a progressively depleting soil moisture profile. Previous studies indicated that drought during the vegetative phase has small effect on growth and yield of peanut (Awal and Ikeda, 2002), and 24\% of yield reduction was reported when peanut was subjected to drought during the end of growing season (Boontang et al., 2010; Girdthai et al., 2010).

Breeding drought resistance peanut during later drought stage required information on physiological

\footnotetext{
${ }^{1}$ Khon Kaen University, Faculty of Agriculture, Muang, Khon Kaen, 40002, Thailand. *Corresponding author (sanun@kku.ac.th).

${ }^{2}$ Suranaree University of Technology, Institute of Agricultural Technology, Nakhon Ratchasima 30000, Thailand.

Received: 11 November 2013.

Accepted: 17 June 2014.

doi:10.4067/S0718-58392014000300001
}

traits and morphological response and the mechanism of adaptability to reduced yield loss. Previous study reported the response of physiological traits and yield, whereas the information of root characteristic was limit. However, the previous work showed the information of root traits under early drought (Jongrungklang et al., 2011), mid-season drought (Jongrungklang et al., 2012), and long term drought conditions (Songsri et al., 2008) except terminal drought condition.

In peanut, the selection for drought resistance in the past has primarily been based on pod yield under drought conditions. Moreover, drought resistance can be enhanced by improving the ability of peanut to extract water from soil (Wright and Nageswara Rao, 1994). Root traits such as root length density, rooting depth and root distribution have been identified as drought resistance (Matsui and Singh, 2003). Information on the ability on drought resistant peanut genotypes consists of maximum water uptake through improving the capacity of root system to acquire water and optimization of water use for yield production (Subbarao at al., 1995). Songsri et al. (2008) reported that peanut genotypes with large root system and root depth could maintain high plant water status and gave high yield under long term drought condition. However, root response at the terminal drought can be an important mechanism to maintain high pod yield and use as a selection criteria for drought tolerance in peanut. 
Limited information has been available for the response of peanut genotypes to terminal drought for root systems. A better understanding on how peanut genotypes respond to terminal drought for root traits is important for drought resistance cultivars. Breeding for drought tolerance can increase long-term productivity under drought conditions. The objectives of this study were (i) to evaluate root characteristics of peanut genotypes that may affect terminal drought conditions, (ii) to investigate the effect of terminal drought on peanut yield, and (iii) to determine the relationship between root traits and peanut yield under drought conditions. This information is helpful to determine future strategies for peanut breeding in dry areas.

\section{MATERIALS AND METHODS}

\section{Experimental design}

The experiments were conducted at field crop research station of Khon Kaen University, Khon Kaen province, Thailand, during the dry season 2004-2005 (from November 2004 to February 2005) and were repeated during the dry season 2005 (from September to December 2005). The experiment was set up in a $2 \times 11$ factorial in randomized complete block design (RCBD) with four replicates with two water regimes (field capacity [FC]; FC and 1/3 soil available water [AW]; 1/3 AW from $80 \mathrm{~d}$ after planting [DAP] to harvest) as factor $A$ and 11 peanut genotypes as factor B.

Eleven peanut genotypes were selected on the basis of their diversity in drought tolerance. The peanut genotypes consisted of eight drought-tolerant from the International Crops Research Institute for the Semi-arid Tropics (ICRISAT) (ICGV 98300, ICGV 98303, ICGV 98305, ICGV 98308, ICGV 98324, ICGV 98330, ICGV 98348, and ICGV 98353), one drought-tolerant ('Tifton 8') with a large root system from the United States Department of Agriculture (USDA) (Coffelt et al., 1985), and two commercial genotypes from Thailand ('Tainan 9' and 'KK60-3').

Each pot had a diameter of $25 \mathrm{~cm}$ and a height of 70 $\mathrm{cm}$. Each pots were filled with $42 \mathrm{~kg}$ Yasothon soil series (fine-loamy; siliceous, isohypothermic, Oxic Paleustults), a bulk density of $1.42 \mathrm{~g} \mathrm{~cm}^{-3}$. Soil texture was sandy loam (sand $70 \%$, silt $22.5 \%$, and clay $7.5 \%$ ). Water holding capacity at FC and 1/3 AW were $12.90 \%$ and $6.48 \%$, respectively. Soil columns were filled up to $60 \mathrm{~cm}$ high. The seedlings were two plants per pot. Diseases and insect pests were adequately controlled throughout the study. Plants were maintained weed free by hand weeding.

\section{Water management}

Three cement tubes of each experimental unit were installed to supply water at 25,40 , and $55 \mathrm{~cm}$ from the top of the pot. The experiment pots were two soil moisture levels (FC and 1/3 AW at $80 \mathrm{DAP}$ to final harvest) for 2 yr (2004-2005 and 2005-2006). Water was applied to pots to obtain FC $1 \mathrm{~d}$ before planting and FC was maintained until harvest. Water was withheld at 60 DAP for $20 \mathrm{~d}$ to allow soil moisture to gradually decrease to meet predetermined levels of $1 / 3 \mathrm{AW}$ at $80 \mathrm{DAP}$, and it was maintained at $1 / 3 \mathrm{AW}$ until harvest in the stress treatment. Irrigation was applied regularly to control soil moisture contents at predetermined levels, and the difference from predetermined level for each moisture level was not lower or higher than $1 \%$. The amount applied to each water treatment was calculated by crop water requirement and surface evaporation using the formula of Doorenbos and Pruitt (1992) and Singh and Russell (1981), respectively.

\section{Soil moisture and weather data collection}

Soil moisture in each pot was measured at planting, 80 DAP and final harvest at the depth $0-60 \mathrm{~cm}$ using the gravimetric method. Rainfall, relative humidity $(\mathrm{RH})$, maximum and minimum air temperature, evaporation $\left(\mathrm{E}_{0}\right)$, and solar radiation were recorded daily from planting until final harvest by a meteorological station located $50 \mathrm{~m}$ from the study field. The experiment was conducted in an open-sided greenhouse with transparent roof, and weather data from meteorological station could be used except for rainfall. There was zero rain in 20042005 growing period, whereas most of rainfall occurred at the end of 2005-2006. Total rainfall was $23 \mathrm{~mm}$, which was recorded during 80 to 100 DAP. The rainfall was not affected for greenhouse experiment. Differences between years in rainfall, $\mathrm{RH}$, and solar radiation were very small. The maximum and minimum air temperature ranged from 10 to $36{ }^{\circ} \mathrm{C}$ in $2004-2005$ and 12 to $38{ }^{\circ} \mathrm{C}$ in $2005-2006$.

\section{Root characters evaluation}

The root traits of each pot were evaluated at final harvest. Root samples of each pot were washed manually on a wire mesh screen with tap water to remove soil and debris. Root samples were analyzed with the WinRHIZO program (WinRHIZO Pro (s) V.2004a, Regent Instruments, SainteFoy-Sillery-Cap-Rouge, Quebec, Canada) to determine root length (RL), root surface (RS), average root diameter (RD), and root volume (RV) per sample. Root samples were oven-dried at $80^{\circ} \mathrm{C}$ for $48 \mathrm{~h}$ or until constant weight and root dry weight (RDW) was determined.

\section{Pod dry weight (PDW), biomass (BM), and harvest index (HI) evaluation}

At the final harvest, biomass, pod yield, and harvest index were obtained from two plants in each pot. Fresh weight was determined and was oven-dried at $80{ }^{\circ} \mathrm{C}$ for $48 \mathrm{~h}$ or until constant weight and dry weight was measured. Biomass included total shoot and root, and pod yield per plant was also calculated. Pods were removed from the plant and air-dried to approximately $8 \%$ soil moisture and pod dry weight was determined. Harvest index was computed as the ratio of pod yield to biomass at harvest. 


\section{Statistical analysis}

ANOVA was performed for total pod yield, biomass, HI, and root traits in each year according to a randomized complete block design. Test of error variance homogeneity was performed, and when variances were homogenous, 2 yr data were combined and then analyzed using Statistix 8 (Analytical Software, Tallahassee, Florida, USA). Mean differences among genotypes were separated by Duncan's Multiple-Range Test (DMRT) at $\mathrm{P} \leq 0.05$. Simple correlation was used to determine the relationship between peanut root characteristics and yield (pod dry weight, biomass) and HI. Moreover, mean differences among water regimes were calculated by t-test in all peanut genotypes.

\section{RESULTS}

\section{Soil water content}

The soil water content of both water regimes showed clear differences in 2 yr. Soil water content under drought conditions decreased from 80 DAP to final harvest compared to non-stress treatment. Soil moisture in the stress treatment at final harvest $(6.48 \%$ in $2004-2005$ and $6.40 \%$ in 2005-2006) was less than the non-stress treatment $(12.84 \%$ in $2004-2005$ and $13.26 \%$ in 2005 2006) (Figure 1a and 1b). These results confirmed soil water content, indicating that degree of drought was reasonably controlled at the predetermined levels.

\section{Combined ANOVA}

Water regimes were significantly different for all root characters, PDW, BM, and HI. Genotypes were significantly different for all characters and years were significantly different for all characters except RL and HI (Table 1). The interaction for water regimes and genotypes $(\mathrm{W} \times \mathrm{G})$ was significant for RDW, RL, and RD but they were not significant for RS, RV, PDW, BM, and HI. The interactions between year and water regimes $(\mathrm{Y} \times \mathrm{W})$ were significant for RD and RV, but they were not significant for RDW, RL, RS, PDW, BM, and HI. The interactions between year and genotypes $(\mathrm{Y} \times \mathrm{G})$ were significant for RL, RD, and PDW, but they were not significant for RDW, RS, RV, BM, and HI. The interactions between
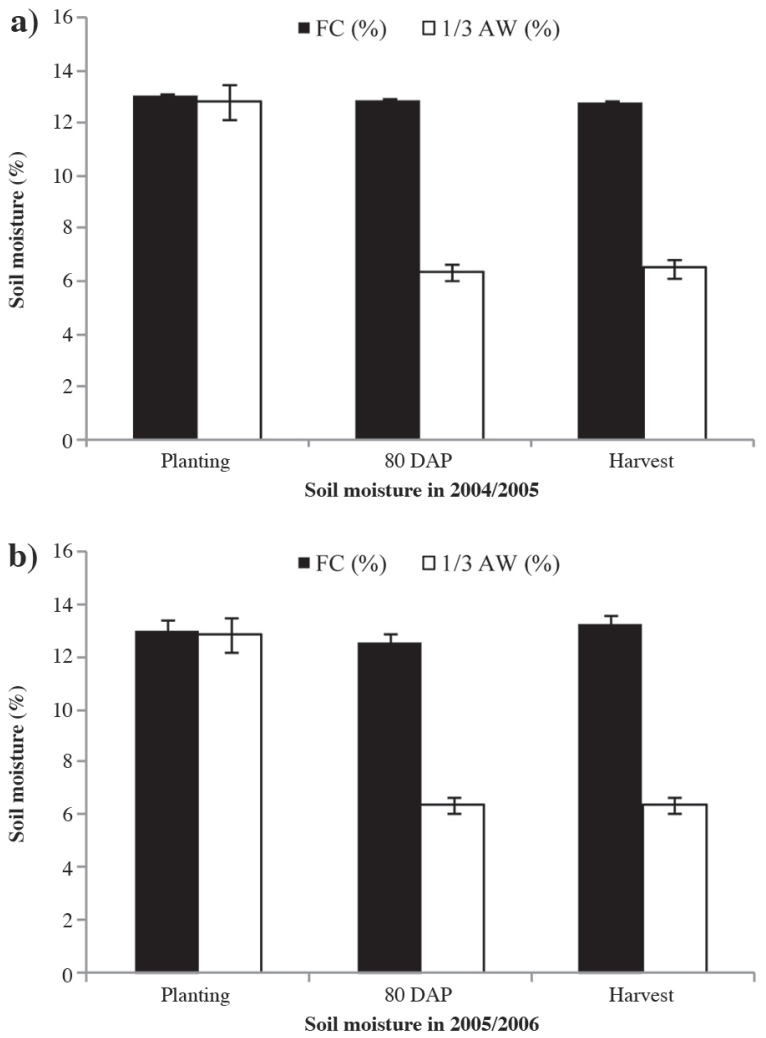

Figure 1. Gravimetric soil moisture under different water regimes: Field capacity (FC) and $1 / 3$ available water $(1 / 3 \mathrm{AW})$ at $60 \mathrm{~d}$ after planting (DAP) for $20 \mathrm{~d}$ to allow soil moisture to gradually decrease to meet the predetermined levels of 1/3 AW at $80 \mathrm{DAP}$ until harvest. Average from 0-60 cm depth at planting, $80 \mathrm{DAP}$ and at final harvest in 2004-2005 (a) and 2005-2006 (b).

year, water regimes and genotype $(\mathrm{Y} \times \mathrm{W} \times \mathrm{G})$ were significant for all of root characters except RDW, but they were not significant for PDW, BM, and HI. The result of this study showed that terminal drought has more effect on root characters and peanut yield.

Effect of terminal drought conditions for root characteristics for two seasons

Year 1 (2004-2005). Drought significant reduced all of root characters in the 2004-2005 (Table 2). Significant differences among peanut genotypes were found for

Table 1. Mean squares from the combined ANOVA for root dry weight (RDW), root length (RL), root surface (RS), root diameter (RD), root volume (RV), pod dry weight (PDW), biomass (BM), and harvest index (HI) at harvest under two water regimes 11 genotypes in $2004-2005$ and 2005-2006.

\begin{tabular}{|c|c|c|c|c|c|c|c|c|c|}
\hline SOV & $\mathrm{DF}$ & RDW & RL & RS & RD & RV & PDW & $\mathrm{BM}$ & $\mathrm{HI}$ \\
\hline Year (Y) & 1 & $1.46^{*}$ & 6211523 & $20.88^{*}$ & $1.56^{* *}$ & $63.67^{* * *}$ & $74.41^{*}$ & $340.33^{*}$ & 0.001 \\
\hline Rep within Y & 3 & 0.05 & 208913 & 2076 & 0.01 & 0.99 & 11.06 & 103.79 & 0.004 \\
\hline Water regime $(\mathrm{W})$ & 1 & $2.16^{* *}$ & $20350000^{* *}$ & $827374^{* *}$ & $0.22^{* *}$ & $77.85^{* * *}$ & $829.29^{* *}$ & $2108.39^{* * *}$ & $0.173^{* *}$ \\
\hline Genotype $(\mathrm{G})$ & 10 & $0.12^{* *}$ & $3920701^{* *}$ & $68366 * *$ & $0.04^{* *}$ & $5.97^{* *}$ & $13.24^{* *}$ & $97.89^{* *}$ & $0.013^{* *}$ \\
\hline $\mathrm{W} \times \mathrm{G}$ & 10 & $0.06^{*}$ & $1721974^{* *}$ & 19824 & $0.01^{* * *}$ & 1.57 & 3.79 & 13.77 & 0.002 \\
\hline $\mathrm{Y} \times \mathrm{W}$ & 1 & 0.04 & 565004 & 31161 & $0.19^{* *}$ & $14.89^{* *}$ & 6.6 & 19.94 & 0.0006 \\
\hline $\mathrm{Y} \times \mathrm{G}$ & 10 & 0.03 & $1546265^{* *}$ & 15100 & $0.02^{\text {** }}$ & 1.71 & $6.48^{*}$ & 17.37 & 0.002 \\
\hline $\mathrm{Y} \times \mathrm{W} \times \mathrm{G}$ & 10 & 0.02 & $757761^{*}$ & $28706 * *$ & $0.01^{*}$ & $3.14^{* *}$ & 2.72 & 3.84 & 0.002 \\
\hline Pooled error & 126 & 0.02 & 381818 & 10739 & 0.004 & 0.95 & 2.78 & 12.77 & 0.002 \\
\hline
\end{tabular}

DF: Degree of freedom.

*Significant at $\mathrm{p} \leq 0.05$.

${ }^{* *}$ Significant at $\mathrm{p} \leq 0.01$. 
Table 2. Total root dry weight (RDW), root length (RL), root surface (RS), average root diameter (RD), and root volume (RV) at final harvest under field capacity (FC) and 1/3 available water (1/3 AW) in 2004-2005.

\begin{tabular}{|c|c|c|c|c|c|c|c|c|c|c|c|c|c|c|c|}
\hline \multirow[b]{2}{*}{ Genotypes } & \multicolumn{3}{|c|}{ RDW } & \multicolumn{3}{|c|}{ RL } & \multicolumn{3}{|c|}{ RS } & \multicolumn{3}{|c|}{ RD } & \multicolumn{3}{|c|}{ RV } \\
\hline & FC & $1 / 3 \mathrm{AW}$ & T-test & FC & $1 / 3 \mathrm{AW}$ & T-test & $\mathrm{FC}$ & $1 / 3 \mathrm{AW}$ & T-test & $\mathrm{FC}$ & $1 / 3 \mathrm{AW}$ & T-test & $\mathrm{FC}$ & $1 / 3 \mathrm{AW}$ & T-test \\
\hline & \multicolumn{3}{|c|}{$\longrightarrow$ g plant $^{-1}$} & \multicolumn{3}{|c|}{$\mathrm{cm} \mathrm{plant}^{-1}$} & \multicolumn{3}{|c|}{$-\mathrm{cm}^{2}$ plant $^{-1}$} & \multicolumn{3}{|c|}{- mm plant $^{-1}$} & \multicolumn{3}{|c|}{$-\mathrm{mm}^{3}$ plant $^{-1}$} \\
\hline ICGV98300 & $1.01 \mathrm{bcd}$ & 0.77 & ** & $4518 \mathrm{abc}$ & $3596 \mathrm{bcd}$ & $1 \quad * *$ & 639abc & $514 \mathrm{ab}$ & $*$ & 0.45 & $0.48 \mathrm{a}$ & ns & 7.19abcd & $5.55 \mathrm{ab}$ & ns \\
\hline ICGV98303 & $1.06 \mathrm{bcd}$ & 0.84 & ns & $4989 a$ & $3284 d$ & $* *$ & $694 \mathrm{ab}$ & $421 b$ & $* *$ & 0.44 & $0.45 \mathrm{abcd}$ & ns & $8.13 \mathrm{abc}$ & $4.71 \mathrm{~b}$ & $*$ \\
\hline ICGV98305 & $1.13 \mathrm{abc}$ & 0.88 & ns & 4061 bcd & $4180 \mathrm{ab}$ & ns & $578 \mathrm{bc}$ & $620 \mathrm{a}$ & ns & 0.46 & $0.45 \mathrm{ab}$ & $\mathrm{ns}$ & $6.02 \mathrm{c}$ & $6.66 \mathrm{a}$ & ns \\
\hline ICGV98308 & $1.00 \mathrm{bcd}$ & 0.79 & ns & 4040bcd & $3599 b c d$ & ns & $602 a b c$ & $449 b$ & ns & 0.43 & $0.46 \mathrm{ab}$ & ns & $6.49 \mathrm{bcd}$ & $4.76 \mathrm{~b}$ & ns \\
\hline ICGV98324 & $1.01 \mathrm{bcd}$ & 0.79 & $*$ & 3803 bcd & $4382 \mathrm{a}$ & ns & $541 \mathrm{bc}$ & $388 b$ & ns & 0.45 & $0.46 \mathrm{ab}$ & ns & $6.23 \mathrm{~cd}$ & $4.71 \mathrm{~b}$ & $\mathrm{~ns}$ \\
\hline ICGV98330 & $0.93 \mathrm{~cd}$ & 0.91 & ns & 3885 bcd & $3561 \mathrm{~cd}$ & ns & $572 \mathrm{bc}$ & $493 \mathrm{ab}$ & ns & 0.46 & $0.40 \mathrm{~d}$ & ns & 6.80abcd & $5.31 \mathrm{ab}$ & $\mathrm{ns}$ \\
\hline ICGV98348 & $0.85 \mathrm{~d}$ & 0.77 & $\mathrm{~ns}$ & $3513 d$ & $3399 \mathrm{~cd}$ & ns & $537 \mathrm{bc}$ & $380 \mathrm{~b}$ & ns & 0.43 & $0.42 \mathrm{bcd}$ & ns & $5.44 \mathrm{~d}$ & $4.52 b$ & ns \\
\hline ICGV98353 & $1.16 \mathrm{ab}$ & 0.76 & $\mathrm{~ns}$ & $5232 \mathrm{a}$ & $3902 \mathrm{abc}$ & $* *$ & $753 a$ & $435 b$ & $* *$ & 0.43 & $0.45 \mathrm{abc}$ & $\mathrm{ns}$ & $8.47 \mathrm{ab}$ & $5.58 \mathrm{ab}$ & $* *$ \\
\hline Tainan 9 & 0.98 bcd & 0.79 & ns & $3645 \mathrm{~cd}$ & $3435 \mathrm{~cd}$ & ns & $602 \mathrm{abc}$ & $361 b$ & $*$ & 0.45 & $0.43 \mathrm{bcd}$ & ns & $6.90 \mathrm{abcd}$ & $4.62 \mathrm{~b}$ & $*$ \\
\hline KK60-3 & $1.31 \mathrm{a}$ & 0.97 & $*$ & $4977 \mathrm{a}$ & $4306 a$ & ns & $653 \mathrm{abc}$ & $500 \mathrm{ab}$ & $* *$ & 0.46 & $0.48 \mathrm{a}$ & ns & $8.06 \mathrm{abc}$ & $5.13 \mathrm{~b}$ & $* *$ \\
\hline Tifton- 8 & $1.33 \mathrm{a}$ & 0.76 & $* *$ & $4682 \mathrm{ab}$ & $3466 \mathrm{~cd}$ & $* *$ & $672 \mathrm{abc}$ & $479 \mathrm{ab}$ & $*$ & 0.46 & $0.44 \mathrm{abcd}$ & ns & $8.64 a$ & $5.80 \mathrm{ab}$ & $* *$ \\
\hline F-test & $* *$ & ns & & *** & ** & & $* *$ & *** & & ns & & & & & \\
\hline Mean & 1.07 & 0.83 & & 4234 & 3698 & & 612 & 460 & & 0.44 & 0.43 & & 7.00 & 5.24 & \\
\hline $\mathrm{CV}(\%)$ & 15.26 & 18.98 & & 14.52 & 10.85 & & 16.80 & 23.72 & & 6.84 & 8.91 & & 18.97 & 18.04 & \\
\hline
\end{tabular}

T-test is the differences among water regimes in 11 peanut genotypes.

Mean in the same column with the same letters are not significantly different by Duncan's Multiple-Range Test (DMRT).

* Significant $\mathrm{P} \leq 0.05 ;{ }^{* *} \mathrm{P} \leq 0.01$; ns $=$ non-significant.

RDW, RL, RS, and RV under FC and $1 / 3$ AW except for RDW at $1 / 3 \mathrm{AW}$ and RD at FC. There were not significant differences for RD under two water regimes.

Genotypes differed significantly for RDW at FC and $1 / 3$ AW with mean values ranging from 1.07 and 0.83 $\mathrm{g} \mathrm{plant}^{-1}$ (Table 2). Root dry weight decreased when peanut genotypes were exposed to terminal drought, but genotypes were not significant for RDW under stress condition. In this study, ICGV98300, ICGV98324, 'KK60-3', and 'Tifton 8' showed significant decreased in RDW under stress condition. The genotypes showing higher at FC were 'Tifton 8' and 'KK60-3'. Peanut genotypes differed significantly for RL at FC and $1 / 3$ AW with mean values ranging from 4234 and $3698 \mathrm{~cm}$ plant $^{-1}$. ICGV98300, ICGV98303, ICGV98353, and 'Tifton 8' showed significant decrease in RL under $1 / 3$ $\mathrm{AW}$ condition. The genotypes showing higher at $1 / 3 \mathrm{AW}$ was ICGV98324 and KK60-3 also showed high RL at FC and $1 / 3$ AW conditions.
Genotypes showed significant decrease for RS at $1 / 3$ AW were ICGV98300, ICGV98303, ICGV98353, 'Tainan 9', 'KK60-3', and 'Tifton 8', and the genotype showing higher RS at 1/3 AW was ICGV98305. Peanut genotypes differed significantly for RD at $1 / 3 \mathrm{AW}$ with mean values was $0.43 \mathrm{~mm}$ plant $^{-1}$. ICGV98300 and 'KK60-3' gave higher RD at 1/3 AW. Genotypes differed significantly for $\mathrm{RV}$ at $\mathrm{FC}$ and $1 / 3 \mathrm{AW}$ with mean values ranging from 7.00 and $5.24 \mathrm{~mm}^{3}$ plant $^{-1}$. ICGV98303, ICGV98353, 'Tainan 9', 'KK60-3', and 'Tifton 8' showed significant decreased in $\mathrm{RV}$ under $1 / 3 \mathrm{AW}$ condition. The genotypes showing higher at FC were 'Tifton 8', while ICGV98305 gave high RD at $1 / 3 \mathrm{AW}$.

Year 2 (2005-2006). Drought significant reduced all root characters in 2005-2006 (Table 3). Significant differences among peanut genotypes were found for RDW, RL, RS, RD, and RV under FC and 1/3 AW conditions. Genotypes differed significantly for RDW at FC and $1 / 3$ AW with

Table 3. Total root dry weight (RDW), root length (RL), root surface (RS), average root diameter (RD), and root volume (RV) at final harvest under field capacity $(\mathrm{FC})$ and $1 / 3$ available water $(1 / 3 \mathrm{AW})$ in 2005-2006.

\begin{tabular}{|c|c|c|c|c|c|c|c|c|c|c|c|c|c|c|c|}
\hline \multirow[b]{2}{*}{ Genotypes } & \multicolumn{3}{|c|}{ RDW } & \multicolumn{3}{|c|}{ RL } & \multicolumn{3}{|c|}{ RS } & \multicolumn{3}{|c|}{$\mathrm{RD}$} & \multicolumn{3}{|c|}{ RV } \\
\hline & $\mathrm{FC}$ & $1 / 3 \mathrm{AW}$ & T-test & $\mathrm{FC}$ & $1 / 3 \mathrm{AW}$ & T-test & $\mathrm{FC}$ & $1 / 3 \mathrm{AW}$ & T-test & $\mathrm{FC}$ & $1 / 3 \mathrm{AW}$ & T-test & $\mathrm{FC}$ & $1 / 3 \mathrm{AW}$ & T-test \\
\hline & \multicolumn{3}{|c|}{$\longrightarrow$ g plant $^{-1} \longrightarrow$} & \multicolumn{3}{|c|}{$-\mathrm{cm} \mathrm{plant}^{-1}$} & \multicolumn{3}{|c|}{$-\mathrm{cm}^{2}$ plant $^{-1}-$} & \multicolumn{3}{|c|}{$-\mathrm{mm} \mathrm{plant}^{-1}$} & \multicolumn{3}{|c|}{$-\mathrm{mm}^{3}$ plant $^{-1}-$} \\
\hline ICGV98300 & 1.14def & $0.97 \mathrm{ab}$ & ns & 4906bcd & 4453abcd & ns & $658 \mathrm{bc}$ & $502 \mathrm{bcd}$ & * & $0.69 \mathrm{bc}$ & $0.54 \mathrm{abc}$ & $\mathrm{ns}$ & $5.64 \mathrm{~cd}$ & $4.48 \mathrm{cdef}$ & * \\
\hline ICGV98303 & $1.32 \mathrm{bc}$ & $1.17 \mathrm{a}$ & $\mathrm{ns}$ & $5500 \mathrm{ab}$ & 3919bcd & $* *$ & $767 \mathrm{ab}$ & $551 \mathrm{bc}$ & * & $0.83 \mathrm{a}$ & $0.54 \mathrm{abc}$ & ** & $6.17 \mathrm{bc}$ & 4.63bcde & *** \\
\hline ICGV98305 & $1.40 \mathrm{ab}$ & $1.05 \mathrm{ab}$ & $*$ & $5905 a$ & $4507 \mathrm{abc}$ & ns & $774 a$ & $568 \mathrm{abc}$ & $* *$ & $0.81 \mathrm{a}$ & $0.62 \mathrm{a}$ & $* *$ & $7.10 \mathrm{a}$ & $5.23 \mathrm{abc}$ & * \\
\hline ICGV98308 & $1.30 \mathrm{bc}$ & $1.03 \mathrm{ab}$ & $* *$ & $5310 \mathrm{ab}$ & $3286 \mathrm{~cd}$ & $* *$ & $596 \mathrm{~cd}$ & $492 \mathrm{bcd}$ & $\mathrm{ns}$ & $0.69 \mathrm{bc}$ & $0.60 \mathrm{a}$ & $* *$ & $5.58 \mathrm{cde}$ & 4.19def & $*$ \\
\hline ICGV98324 & $1.09 \mathrm{ef}$ & $0.98 \mathrm{ab}$ & ns & $2850 \mathrm{e}$ & $3226 d$ & ns & 498de & $487 \mathrm{bcd}$ & ns & $0.48 \mathrm{e}$ & $0.58 \mathrm{ab}$ & ns & $4.84 \mathrm{ef}$ & $4.37 \mathrm{cdef}$ & ns \\
\hline ICGV98330 & $1.03 \mathrm{f}$ & $0.86 b$ & ns & $4288 d$ & $3297 \mathrm{~cd}$ & ns & $557 \mathrm{cde}$ & $385 d$ & $* *$ & $0.55 \mathrm{de}$ & $0.40 \mathrm{c}$ & $*$ & $5.11 \mathrm{def}$ & $3.67 \mathrm{f}$ & $* *$ \\
\hline ICGV98348 & $1.11 \mathrm{ef}$ & $0.97 \mathrm{ab}$ & ns & $4543 \mathrm{~cd}$ & $3685 \mathrm{bcd}$ & ns & $594 \mathrm{~cd}$ & $427 \mathrm{~cd}$ & $* *$ & $0.62 \mathrm{~cd}$ & $0.45 \mathrm{bc}$ & ns & $4.45 \mathrm{f}$ & $3.76 \mathrm{ef}$ & $\mathrm{ns}$ \\
\hline ICGV98353 & $1.21 \mathrm{cde}$ & $1.10 \mathrm{ab}$ & ns & $5231 \mathrm{abc}$ & 3877 bcd & ns & $649 c$ & 507 bcd & ns & $0.76 \mathrm{ab}$ & $0.57 \mathrm{ab}$ & $\mathrm{ns}$ & $4.66 \mathrm{f}$ & $3.85 \mathrm{ef}$ & $\mathrm{ns}$ \\
\hline Tainan9 & $1.09 \mathrm{ef}$ & $1.08 \mathrm{ab}$ & $\mathrm{ns}$ & $3404 \mathrm{e}$ & 3553bcd & ns & $448 \mathrm{e}$ & $579 \mathrm{abc}$ & ns & $0.70 b c$ & $0.62 \mathrm{a}$ & ns & $3.54 \mathrm{~g}$ & 5.07abcd & $* *$ \\
\hline KK60-3 & $1.27 \mathrm{bcd}$ & $1.10 \mathrm{ab}$ & ns & $4878 \mathrm{bcd}$ & $5594 a$ & $\mathrm{~ns}$ & $652 \mathrm{c}$ & $723 a$ & $\mathrm{~ns}$ & $0.75 \mathrm{ab}$ & $0.68 \mathrm{a}$ & $\mathrm{ns}$ & $5.14 \mathrm{def}$ & $5.83 \mathrm{a}$ & $\mathrm{ns}$ \\
\hline Tifton-8 & $1.49 \mathrm{a}$ & $1.04 \mathrm{ab}$ & $*$ & $5908 \mathrm{a}$ & $4598 \mathrm{ab}$ & $*$ & $849 a$ & $605 \mathrm{ab}$ & $*$ & $0.83 a$ & $0.63 \mathrm{a}$ & $*$ & $6.52 \mathrm{ab}$ & $5.42 \mathrm{ab}$ & $*$ \\
\hline F-test & *** & $*$ & & *** & $*$ & & $* *$ & $*$ & & $* *$ & . & & $* *$ & ** & \\
\hline Mean & 1.22 & 1.03 & & 4631 & 3954 & & 620 & 528 & & 0.68 & 0.57 & & 6.89 & 5.75 & \\
\hline $\mathrm{CV}(\%)$ & 8.50 & 17.50 & & 10.50 & 22.77 & & 12.82 & 21.70 & & 9.43 & 14.78 & & 10.62 & 14.61 & \\
\hline
\end{tabular}

T-test is the differences among water regimes in 11 peanut genotypes.

Mean in the same column with the same letters are not significantly different by Duncan's Multiple-Range Test (DMRT).

${ }^{*}$ Significant at $\mathrm{P} \leq 0.05 ;{ }^{* *} \mathrm{P} \leq 0.01 ; \mathrm{ns}=$ non-significant. 
mean values ranging from 1.22 and $1.03 \mathrm{~g} \mathrm{plant}^{-1}$ (Table 3). ICGV98305, ICGV98308, and 'Tifton 8' showed significant decrease at $1 / 3 \mathrm{AW}$, and ICGV98303 gave highest RDW than other genotypes under 1/3 AW condition. Genotypes differed significantly for RL at FC and 1/3 AW with mean values ranging from 4631 and $3954 \mathrm{~cm} \mathrm{plant}^{-1}$ (Table 3). ICGV98303, ICGV98308, and 'Tifton 8' showed significant decrease in RL under $1 / 3$ AW condition. Genotypes showing higher RL at FC were 'Tifton 8' and ICGV98305, whereas 'KK60-3' gave high RL under $1 / 3 \mathrm{AW}$ condition.

Drought significantly reduced RS at FC and 1/3 AW, and ICGV98300, ICGV98303, ICGV98305, ICGV98330, ICGV98348, and 'Tifton 8' showed significant decrease in RS under drought condition. Genotypes showing highest RS at FC were 'Tifton 8' and ICGV98305, whereas 'KK60-3' gave highest RL at 1/3 AW. Peanut genotypes were significant different for RD at FC and 1/3 AW. ICGV98303, ICGV98305, ICGV98308, ICGV98330, and 'Tifton 8' showed significant decrease under stress condition when compare with FC condition. ICGV98303, ICGV98305, and 'Tifton 8' gave highest RD under FC condition. In contrast, ICGV98305, ICGV98308, 'Tainan 9', 'KK60-3', and 'Tifton 8' showed highest RD at 1/3 AW when compared with FC condition.

In this study, drought significantly reduced RV for all peanut genotypes when compared with FC condition except for ICGV98324, ICGV98348, ICGV98353, and 'KK60-3'. The genotype showing highest RV at FC was ICGV98305, whereas 'KK60-3' gave high RV under 1/3 AW condition.

\section{Correlation between root traits with pod dry weight, biomass, and harvest index}

The correlation between RDW, RL, RS, and RD with pod dry weight, biomass, and HI were not significant for any water regimes in the 2004-2005 (Table 4). In contrast, there was good correlation between RV and $\mathrm{HI}$ at 1/3 AW $\left(\mathrm{r}=0.83^{* *}\right)$ in the 2004-2005 except biomass and HI.

Correlation of root characters with PDW was not significant under FC and 1/3 AW conditions in the 20052006 (Table 4). The relationship between RDW and BM was highly significant under FC condition $(r=0.72 * *)$.
Moreover, RL had good correlation with BM under 1/3 AW condition $(r=0.71 * *)$ in the second year. Biomass production had good association with RS and RD only under FC condition ( $r=0.58 *$ and $r=0.67 *$, respectively). Harvest index had good correlation with RV under FC condition in the 2005-2006 $(r=0.57 *)$.

\section{DISCUSSION}

Drought is a major cause of the reduction for plant growth and yield in peanut. Our results showed that terminal drought decreased a drastic reduction in root traits and yield in both years and the magnitude of reduction would depend on peanut genotypes (Tables 5 and 6). These results supported previous finding that pod yield were reduced when peanut was subjected to terminal drought (Boontang et al., 2010; Girdthai et al., 2010) and the reduction also varies among peanut genotypes (Harris et al., 1988). Drought related reduction in growth and yield of plants could be ascribed to stomatal closure in response to low soil moisture, which decreased the intake of $\mathrm{CO}_{2}$ and, as a result, photosynthesis decreased (Cornic, 2000; Flexas et al., 2004). In this study, earlier maturing genotypes had greater yield than later maturing genotype under drought condition. This result indicate that early root distribution is completed helping to maintain better partitioning into the seed at the later growth stage under terminal drought conditions leading to better yield (Kashiwagi et al., 2006).

Our results showed that root traits of peanut were not correlated with pod dry weight except biomass and HI under terminal drought. This was associated with vegetative growth (Patel and Golakiya, 1993) and growth stage. Under terminal drought, peanut had low vegetative growth and senescence period. Thus, high stomatal resistance in old leaves reduced photosynthetically active radiation (PAR) absorption in plant. The result may not be the same as that mid-season drought (Jongrungklang et al., 2012) and long term drought (Songsri et al., 2008). These mean that water stress during the vegetative growth stage could keep soil water for their reproductive growth, whereas roots have less ability to response during late growth stage. Moreover, root length had a positive correlation with biomass indicating the root distribution

Table 4. Correlation between root traits root dry weight (RDW), root length (RL), root surface (RS), average root diameter (RD) and root volume (RV), and agronomic yield pod dry weight (PDW), biomass (BM) and harvest index (HI) at final harvest in peanut genotypes under different water regimes in the 2004-2005 and 2005-2006.

\begin{tabular}{|c|c|c|c|c|c|c|c|c|c|c|}
\hline \multirow[b]{2}{*}{ Parameters } & \multicolumn{2}{|c|}{ RDW } & \multicolumn{2}{|c|}{$\mathrm{RL}$} & \multicolumn{2}{|c|}{ RS } & \multicolumn{2}{|c|}{$\mathrm{RD}$} & \multicolumn{2}{|c|}{ RV } \\
\hline & FC & $1 / 3 \mathrm{AW}$ & $\mathrm{FC}$ & $1 / 3 \mathrm{AW}$ & $\mathrm{FC}$ & $1 / 3 \mathrm{AW}$ & $\mathrm{FC}$ & $1 / 3 \mathrm{AW}$ & $\mathrm{FC}$ & $1 / 3 \mathrm{AW}$ \\
\hline \multicolumn{11}{|l|}{ 2004-2005 } \\
\hline PDW & 0.44 & 0.22 & 0.33 & 0.007 & 0.20 & 0.32 & 0.27 & 0.16 & 0.43 & 0.28 \\
\hline $\mathrm{BM}$ & 0.45 & 0.30 & 0.26 & 0.20 & 0.09 & 0.14 & 0.31 & 0.23 & 0.32 & 0.28 \\
\hline $\mathrm{HI}$ & 0.54 & 0.20 & 0.11 & 0.28 & 0.04 & 0.41 & 0.53 & 0.09 & 0.26 & $0.83^{* *}$ \\
\hline \multicolumn{11}{|l|}{$2005-2006$} \\
\hline PDW & 0.37 & 0.22 & 0.48 & 0.31 & 0.28 & 0.12 & 0.51 & 0.2 & 0.04 & 0.01 \\
\hline $\mathrm{BM}$ & $0.72^{* *}$ & 0.20 & 0.56 & $0.71^{* *}$ & $0.58^{*}$ & 0.12 & $0.67^{*}$ & 0.41 & 0.42 & 0.56 \\
\hline $\mathrm{HI}$ & 0.52 & 0.18 & 0.27 & 0.34 & 0.39 & 0.04 & 0.20 & 0.28 & $0.57^{*}$ & 0.36 \\
\hline
\end{tabular}

, ** Significant at the $95 \%$ and $99 \%$ probability levels, respectively; FC: field capacity; AW: available water. 
Table 5. Total pod dry weight (PDW), biomass (BM), and harvest index (HI) at field capacity (FC) and $1 / 3$ available water (1/3 AW) in 20042005.

\begin{tabular}{|c|c|c|c|c|c|c|c|c|c|}
\hline \multirow[b]{2}{*}{ Genotype } & \multicolumn{3}{|c|}{ PDW } & \multicolumn{3}{|c|}{$\mathrm{BM}$} & \multicolumn{3}{|c|}{$\mathrm{HI}$} \\
\hline & $\mathrm{FC}$ & $1 / 3 \mathrm{AW}$ & T-test & $\mathrm{FC}$ & $1 / 3 \mathrm{AW}$ & T-test & $\mathrm{FC}$ & $1 / 3 \mathrm{AW}$ & T-test \\
\hline & & - & $-\mathrm{g} \mathrm{pl}$ & & & 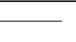 & & & \\
\hline ICGV98300 & $13.26 \mathrm{bcd}$ & $8.71 \mathrm{bcd}$ & $* *$ & $36.23 \mathrm{ab}$ & $25.02 \mathrm{bc}$ & $* *$ & $0.37 \mathrm{~b}$ & $0.35 \mathrm{abc}$ & ns \\
\hline ICGV98303 & $14.66 \mathrm{abc}$ & $9.96 a b$ & ** & $33.47 \mathrm{bc}$ & $26.57 b c$ & $* *$ & $0.44 \mathrm{a}$ & $0.39 \mathrm{ab}$ & $\mathrm{ns}$ \\
\hline ICGV98305 & $12.37 \mathrm{~cd}$ & $8.16 \mathrm{bcd}$ & $*$ & $31.97 \mathrm{bc}$ & $25.87 \mathrm{bc}$ & $*$ & $0.39 \mathrm{ab}$ & $0.32 \mathrm{c}$ & ns \\
\hline ICGV98308 & $12.48 \mathrm{~cd}$ & $8.49 \mathrm{bcd}$ & $*$ & $32.29 b c$ & $23.62 \mathrm{~cd}$ & $\mathrm{~ns}$ & $0.39 \mathrm{ab}$ & $0.36 \mathrm{abc}$ & $\mathrm{ns}$ \\
\hline ICGV98324 & $11.79 \mathrm{~d}$ & $9.16 \mathrm{abc}$ & *** & $29.88 c$ & $25.95 \mathrm{bc}$ & ns & $0.40 \mathrm{ab}$ & $0.36 \mathrm{abc}$ & $\mathrm{ns}$ \\
\hline ICGV98330 & 14.26abcd & $8.45 \mathrm{bcd}$ & $* *$ & $33.10 \mathrm{bc}$ & $25.65 b c$ & $*$ & $0.43 \mathrm{a}$ & $0.33 b c$ & $*$ \\
\hline ICGV98348 & $14.70 \mathrm{abc}$ & $10.89 \mathrm{a}$ & *** & $33.80 \mathrm{bc}$ & $26.88 \mathrm{abc}$ & $* *$ & $0.44 \mathrm{a}$ & $0.41 \mathrm{a}$ & $\mathrm{ns}$ \\
\hline ICGV98353 & $12.11 \mathrm{~cd}$ & $7.67 \mathrm{~cd}$ & $*$ & $27.92 \mathrm{c}$ & $23.10 \mathrm{~cd}$ & ns & $0.43 \mathrm{a}$ & $0.33 b c$ & $*$ \\
\hline Tainan 9 & $11.81 \mathrm{~d}$ & $6.79 \mathrm{~d}$ & ** & $28.66 \mathrm{c}$ & $19.50 \mathrm{~d}$ & $* *$ & $0.41 \mathrm{ab}$ & $0.35 \mathrm{abc}$ & ns \\
\hline KK60-3 & $15.63 \mathrm{ab}$ & $10.26 \mathrm{ab}$ & $*$ & $36.57 \mathrm{ab}$ & $29.10 \mathrm{ab}$ & ns & $0.43 \mathrm{a}$ & $0.36 \mathrm{abc}$ & $*$ \\
\hline Tifton- 8 & $16.75 \mathrm{a}$ & $9.26 \mathrm{abc}$ & $* *$ & $40.67 \mathrm{a}$ & $30.75 a$ & ns & $0.42 \mathrm{ab}$ & $0.30 \mathrm{c}$ & $* *$ \\
\hline F-test & $* *$ & ** & & $*$ & ** & & * & $*$ & \\
\hline Mean & 13.62 & 8.89 & & 33.14 & 25.54 & & 0.41 & 0.35 & \\
\hline $\mathrm{CV}, \%$ & 11.11 & 13.30 & & 12.92 & 11.6 & & 9.29 & 12.52 & \\
\hline
\end{tabular}

T-test is the differences among water regimes in 11 peanut genotypes.

Mean in the same column with the same letters are not significantly different by Duncan's Multiple-Range Test (DMRT).

*Significant at $\mathrm{P} \leq 0.05 ;{ }^{* *} \mathrm{P} \leq 0.01$; ns: non-significant.

Table 6. Total pod dry weight (PDW), biomass (BM), and harvest index (HI) at field capacity (FC) and 1/3 available water (1/3 AW) in 20052006.

\begin{tabular}{|c|c|c|c|c|c|c|c|c|c|}
\hline \multirow[b]{2}{*}{ Genotype } & \multicolumn{3}{|c|}{ PDW } & \multicolumn{3}{|c|}{$\mathrm{BM}$} & \multicolumn{3}{|c|}{ HI } \\
\hline & $\mathrm{FC}$ & $1 / 3 \mathrm{AW}$ & T-test & $\mathrm{FC}$ & $1 / 3 \mathrm{AW}$ & T-test & $\mathrm{FC}$ & $1 / 3 \mathrm{AW}$ & T-test \\
\hline & & 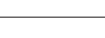 & - g plant $^{-1}$ & & & - & & & \\
\hline ICGV98300 & $10.64 b$ & $8.11 \mathrm{bcd}$ & ns & 29.79abc & $22.87 \mathrm{~cd}$ & * & $0.36 \mathrm{c}$ & $0.34 \mathrm{bc}$ & ns \\
\hline ICGV98303 & $13.11 \mathrm{ab}$ & $9.02 \mathrm{ab}$ & $*$ & $30.62 \mathrm{abc}$ & $23.18 \mathrm{~cd}$ & $*$ & $0.42 b c$ & $0.37 \mathrm{ab}$ & $\mathrm{ns}$ \\
\hline ICGV98305 & $11.57 \mathrm{ab}$ & $8.33 \mathrm{bcd}$ & $* *$ & $28.98 \mathrm{abc}$ & $23.29 \mathrm{~cd}$ & ns & $0.4 \mathrm{bc}$ & $0.37 \mathrm{abc}$ & ns \\
\hline ICGV98308 & $12.93 \mathrm{ab}$ & $7.00 \mathrm{~d}$ & $* *$ & $30.90 \mathrm{abc}$ & $21.54 \mathrm{~cd}$ & ${ }^{*}$ & $0.44 \mathrm{ab}$ & $0.32 \mathrm{bcd}$ & $* *$ \\
\hline ICGV98324 & $10.76 b$ & $7.05 \mathrm{~cd}$ & $*$ & $27.25 b c$ & $24.67 \mathrm{abc}$ & ns & $0.39 b c$ & $0.30 \mathrm{~cd}$ & $*$ \\
\hline ICGV98330 & $10.93 b$ & $7.19 \mathrm{~cd}$ & $*$ & $27.43 b c$ & $21.41 \mathrm{~cd}$ & ${ }^{*}$ & $0.39 b c$ & $0.33 \mathrm{bcd}$ & ns \\
\hline ICGV98348 & $11.87 \mathrm{ab}$ & $10.17 \mathrm{a}$ & ns & $26.54 \mathrm{c}$ & $23.75 b c$ & ns & $0.44 \mathrm{ab}$ & $0.42 \mathrm{a}$ & ns \\
\hline ICGV98353 & $13.81 \mathrm{a}$ & $7.67 \mathrm{bcd}$ & $* *$ & $29.39 \mathrm{abc}$ & $22.60 \mathrm{~cd}$ & $*$ & $0.48 \mathrm{a}$ & $0.36 \mathrm{abc}$ & $* *$ \\
\hline Tainan9 & $11.07 \mathrm{~b}$ & $7.54 \mathrm{bcd}$ & $*$ & $28.47 \mathrm{abc}$ & $20.17 d$ & * & $0.40 \mathrm{bc}$ & $0.36 \mathrm{abc}$ & ns \\
\hline KK60-3 & $13.13 \mathrm{ab}$ & $8.81 \mathrm{abc}$ & $* *$ & $33.98 \mathrm{a}$ & $27.49 \mathrm{a}$ & ${ }^{*}$ & $0.40 \mathrm{bc}$ & $0.33 \mathrm{bc}$ & * \\
\hline Tifton- 8 & $11.44 \mathrm{ab}$ & $6.87 \mathrm{~d}$ & $*$ & $33.20 \mathrm{ab}$ & $26.82 \mathrm{ab}$ & ns & $0.38 b c$ & $0.26 \mathrm{~d}$ & ** \\
\hline F-test & * & $* *$ & & $*$ & $* *$ & & * & $*$ & \\
\hline Mean & 11.93 & 7.98 & & 29.69 & 23.44 & & 0.41 & 0.34 & \\
\hline $\mathrm{CV}, \%$ & 14.95 & 15.70 & & 14.00 & 9.99 & & 9.81 & 14.12 & \\
\hline
\end{tabular}

T-test is the differences among water regimes in 11 peanut genotypes.

Mean in the same column with the same letters are not significantly different by Duncan's Multiple-Range Test (DMRT).

${ }^{*}$ Significant at $\mathrm{P} \leq 0.05 ;{ }^{* *} \mathrm{P} \leq 0.01$; ns: non-significant.

helped to maintain high biomass production at the later growth stage under terminal drought conditions. Ratnakumar and Vadez (2011) also obtained positive correlation for root traits and total dry weight in peanut.

Previous study showed that 'Tifton 8' showed highest root dry weight, maintaining high pod yield in the field under stress condition (Koolachart et al., 2013). In pot experiment, we found that 'KK60-3' gave high root traits, maintained high pod yield under terminal drought condition, while 'Tifton 8' showed high biomass with high root trait. In addition, 'KK60-3' gave high root characters under drought condition, suggested that a large root system and deeper rooting might have helped to acquired necessary soil water under stress condition where soil water is available in deeper soil. This result may contribute to yield maintenance under terminal drought condition. Moreover, 'Tainan 9' showed poor root traits under non-stress conditions and the results were inversely to Jongrungklang et al. (2011), who reported that 'Tainan 9' had high root under drought stress than under well watered conditions. The deep root contributed to biomass and HI under drought condition in Virginia type (Huang and Ketring, 1987).

Harvest index has been recognized as a drought resistance mechanism in peanut plant (Nigam et al., 2005). ICGV98348 had high HI both under stress conditions (Table 5). This means that the root might enhance partitioning of assimilates to developing pod yield that maintain $\mathrm{HI}$ under drought conditions. On the contrary, 'Tifton 8 ' had significantly lower pod yield and HI than those of other genotypes under terminal drought due to the root did not contribute to pod yield under stress condition. Therefore, $\mathrm{HI}$ is related to yield as it represents the portion of total biomass partitioned into the seed. Similar results were observed that root characteristics were important for drought tolerance in peanut (Maiti et al., 2002), rice (Ingram et al., 1995), and turf grasses (Huang et al., 1997). 


\section{CONCLUSION}

In conclusion, drought stress decreased root traits, dry matter, and harvestable yield in peanut. There were not correlated of pod dry weight with all root characters under terminal drought. In contrast, root traits showed relationship with biomass and harvest index (HI). Our results were rather different from previous study, which showed good associations between root traits with peanut yield. Early maturity peanut were exposed to drought stress at terminal stage, it lead to less reduction in root and yield than later maturity genotypes. The main reason due to root growth and pod filling is completed before the development of soil water deficit. However, biomass and $\mathrm{HI}$ of some peanut genotypes under terminal drought was related to root length and root volume. Genotypes having large root system could maintain peanut yield under drought condition. Roots are one of the components among all other components which influence overall performance of peanut under terminal drought condition.

\section{ACKNOWLEDGEMENTS}

This work was supported by the Higher Education Research Promotion and National Research University Project of Thailand, Office of the Higher Education Commission, through the Food and Functional Food Research Cluster of Khon Kaen University. Assistance was also received from the Thailand Research Fund, the Commission of Higher Education and Khon Kaen University for providing financial supports through the Distinguished Research Professor Grant of Professor Dr. Aran Patanothai, and the Plant Breeding Research Center for Sustainable Agriculture.

\section{LITERATURE CITED}

Awal, M.A., and T. Ikeda. 2002. Recovery strategy following the imposition of episodic soil moisture deficit stands of peanut (Arachis hypogaea L.) Journal of Agronomy and Crop Science 188:185-192. doi:10.1046/j.1439-037X.2002.00558.x.

Boontang, S., T. Girdthai, S. Jogloy, C. Akkasaeng, N. Vorasoot, A. Patanothai, et al. 2010. Responses of released cultivars of peanut to terminal drought for traits related to drought tolerance. Asian Journal of Plant Science 9:423-431. doi:10.3923/ ajps.2010.423.431.

Coffelt, T.A., R.O. Hammons, W.D. Branch, R.W. Mozingo, P.M. Phipps, J.C. Smith, et al. 1985. Registration of Tifton 8 peanut germplasm. Crop Science 25:203-203.

Cornic, G. 2000. Drought stress inhibits photosynthesis by decreasing stomatal aperture not by affecting ATP synthesis. Trends in Plant Science 5:187-188.

Doorenbos, J., and W.O. Pruitt. 1992. Calculation of crop water requirements. FAO Irrigation and Drainage Paper nr 24. p. 1-65. FAO, Rome, Italy.

Flexas, J., J. Bota, F. Loreto, G. Cornic, and T.D. Sharkey. 2004. Diffusive and metabolic limitations to photosynthesis under drought and salinity in $\mathrm{C}_{3}$ plants. Plant Biology 6:1-11. doi:10.1055/s-2004-820-867.
Girdthai, T., S. Jogloy, C. Akkasaeng, N. Vorasoot, S. Wongkaew, C.C. Holbrook, et al. 2010. Heritability of, and genotypic correlations between, aflatoxin traits and physiological traits for drought tolerance under end of season drought in peanut (Arachis hypogaea L.) Field Crops Research 118:169-176. doi:10.1016/j. fcr.2010.05.007.

Harris, D., R.B. Matthews, R.C. Nageswara Rao, and J.H. Williams. 1988. The physiological basis for yield difference between four genotypes of groundnut (Arachis hypogaea L.) in response to drought. Experimental Agriculture 24:215-226. doi:10.1017/ S0014479700015969.

Huang, B., R.R. Duncan, and R.N. Carrow. 1997. Drought-resistance mechanisms of seven warmseason turf grasses under surface soil drying: Root aspects. Crop Science 37:1863-1869. doi:10.2135/cr opsci1997.0011183X003700060033x.

Huang, M., and D.L. Ketring. 1987. Root growth characteristics of peanut genotypes. Journal of Agricultural Research of China 36:41-52.

Holbrook, C.C., and H.T. Stalker. 2003. Peanut breeding and genetic resources. Plant Breeding Reviews 22:297-356. doi:10.1002/9780470650202.ch6.

Ingram, K.T., R. Rodriguez, S. Sarkarung, and E.B. Yambo. 1995. Germplasm evaluation and improvement for dry seeded rice in drought-prone environments. p. 55-67. In Ingram, K.T. (ed.) Rain-fed lowland rice. Agricultural Research for High-Risk Environments, Los Baños, Laguna, Philippines.

Jongrungklang, N., B. Toomsan, N. Vorasoot, S. Jogloy, K.J. Boote, G. Hoogenboom, et al. 2011. Rooting traits of peanut genotypes with different yield responses to pre-flowering drought stress. Field Crops Research 120:262-270. doi:10.1016/j.fcr.2010.10.008.

Jongrungklang, N., B. Toomsan, N. Vorasoot, S. Jogloy, K.J. Boote, G. Hoogenboom, et al. 2012. Classification of root distribution patterns and their contributions to yield in peanut genotypes under mid-season drought stress. Field Crops Research 127:181-190. doi:10.1016/j.fcr.2011.11.023.

Kashiwagi, J., L. Krishnamurthy, J.H. Crouch, and R. Serraj. 2006. Variability of root length density and its contributions to seed yield in chickpea (Cicer arietinum L.) under terminal drought stress. Field Crops Research 95:171-181. doi:10.1016/j.fcr.2005.02.012.

Koolachart, R., S. Jogloy, N. Vorasoot, S. Wongkaew, C.C. Holbrook, N. Jongrungklang, et al. 2013. Rooting traits of peanut genotypes with different yield response to terminal drought. Field Crops Research 149:366-378. doi:10.1016/j.fcr.2013.05.024.

Maiti, R.K., P. Wesche-Ebeling, A. Nunez-Gonzalez, and E. SanchezArreos. 2002. Root system and mineral nutrition. p. 125-146. In Maiti, R.K., and P. Wesche-Ebeling (eds.) The peanut (Arachis hypogaea) crop. Science Publishers, Enfield, New Hampshire, USA.

Matsui, T., and B.B. Singh. 2003. Root characteristics in cowpea related to drought tolerance at the seedling stage. Experimental Agriculture 39:29-38. doi:10.1017/S0014479703001108.

Nageswara Rao, R.C., J.H. William, and M. Singh. 1989. Genotypic sensitivity to drought and yield potential of peanut. Agronomy Journal 81:887-893. doi:10.2134/agronj1989.000219620081000 60009x.

Nigam, S.N., S. Chandra, S.K. Rupa, B.A. Manoha, G.S. Reddy, R.C. Nageswara Rao, et al. 2005. Efficiency of physiological traitbased and empirical selection approaches for drought tolerance in groundnut. Annals of Applied Biology 146:433-439. doi:10.1111/ j.1744-7348.2005.040076.x.

Patel, M.S., and B.A. Golakiya. 1993. Water stress and aging effects on biophysical parameters of field crops. Indian Journal of Agricultural Research 27:110-114.

Ratnakumar, P., and V. Vadez. 2011. Groundnut (Arachis hypogaea) genotypes tolerant to intermittent drought maintain a high harvest index and have small leaf canopy under stress. Functional Plant Biology 38:1016-1023. doi:10.1071/FP11145. 
Singh, S., and M.B. Russell. 1981. Water use by a maize/pigeonpea intercrop on a deep Vertisol. p. 271-282. In Proceedings of International Workshop on Pigeonpeas, Patancheru, India. 15-19 December 1980. ICRISAT Center, Patancheru, Andhra Pradesh, India.

Songsri, P., S. Jogloy, N. Vorasoot, C. Akkasaeng, A. Patanothai, and C.C. Holbrook. 2008. Root distribution of drought resistance peanut genotypes in response to drought. Journal of Agronomy and Crop Science 194:92-103. doi:10.1111/j.1439037X.2008.00296.x
Subbarao, G.V., C. Johansen, A.E. Slinkard, R.C. Nageswara Rao, N.P. Saxena, and Y.S. Chauhan. 1995. Strategies for improving drought resistance in grain legumes. Critical Reviews in Plant Sciences 14:469-523. doi:10.1080/07352689509701933.

Wright, G.C., and R.C. Nageswara Rao. 1994. Groundnut water relations. p. 281-325. In Smartt, J. (ed.) The Groundnut crop: A scientific basis for improvement. Chapman \& Hall, London, UK. 